\title{
The Basic Framework of Bukharin's Ideas about the Relationship between Planning and Market
}

\author{
Yanning $\mathrm{Hu}$ \\ Yangzhou University Department of Political Science \\ 225009, Yangzhou, China
}

\begin{abstract}
Bukharin proposed the introduction of market relations in the exploration of socialist construction. He practices on the basis of the new economic policy, emphasizing the importance of market relations, to plan and market combine to maintain a reasonable proportion of plan and market. Bukharin's ideas about the relationship between planning and the market does not have a completed discourse, but we can outline some of the main ideas from national economic balance theory, through market relations to grow into a socialist ideology and the theory of toward Socialist for a long time .Delve into Bukharin thought about planning and market relations can promote our understanding of the Bukharin's related economic thought, while further advancing the understanding of the socialist market economic thought.
\end{abstract}

Keywords-bukharin; planning and market; relationship; a reasonable proportion

\section{THE RELATED CONCEPTS}

\section{A. The Concept of Planned Economy and Plans}

In a broad sense, the planned economy" from a centrally planned units rely on executive orders issued for the enterprise production targets and economic resources needed to provide the same way, then the ratio of accumulation and consumption in accordance with established corporate profits are allocated to"1. Plan is the performance of an economic policy, its true meaning is "according to a single plan to centralize the management of all economic activity in order to follow a clear way for individual target service" 2 . Bukharin understood the plan and said roughly the same point of view, the plan is able to rationalize the proletariat, to be organized, planned management. But Bukharin put forward some demands of the program, emphasizing plans to take into account the proportion of under ideal condition, that is, under conditions of perfect competition formed by the action of market forces, which is planned to be "pre-estimated (first thought) in the self-regulation under to determine when something "3. Bukharin for a planned economy to understand that one of the fundamental tasks of the planned economy is to maintain a balance, not only in this balance between the proportion of the production sector, but also in industry, agriculture, manufacturing and other consumer and economic life of the individual aspects.

\section{B. The Concept of Market and Market Relations}

Market broadly refers to a group of firms and individuals to buy and sell some goods and other firms and individuals linked. Narrowly on the market means that buyers and sellers exchange goods. According to Jerome McCarthy $<$ Basic
Marketing>is defined as: Market refers to a group of potential customers with similar needs; their willingness to something of value in exchange for goods or services provided by the seller, such goods or services to meet the needs of the way..Market refers to the relationship between production, supply and sales, specific means trading relationship, which is the process of circulation. Bukharin think in terms of the market relative to the plan, the proletariat can not make their own development in the early stages of a planned rationalization and managed.

Market relations broadly refers to the relationship between suppliers and customers as buyers and sellers, including customer and supplier relationships, distribution channel relationships between customers and service providers and other 17 kinds of relationships. Improved market depends largely on the improvement of relations between the micro-market relations. Internal marketing is an important condition for the success of enterprise marketing. Bukharin discussed mainly the use of market relations law of value in the development of the national economy, combined with the planned regulation with market mechanisms. Essence of market relations are class relations, market competition is the essence of class struggle.

\section{The Concept of the Transitional Period}

We know that the transition period is a theory first proposed by Marx. As a category, in the history of human society, the transition period is specific to private ownership society from capitalism to communism completed the first stage of communism is socialism. Public ownership period, from private to shared transition period. Marx believed that public ownership is due to resolve conflicts arising from private ownership of production, but because the capitalist political superstructure to protect private ownership, public ownership does not arise spontaneously, he produced the proletariat to seize power under the conditions. Therefore, the transitional period is to start generating new regime, the role of government, the private ownership of public ownership have all been replaced, this is the end of the transitional period4. Based on the Soviet Union's social reality, this transition is actually a transition to socialism. During the transition period, various economic elements coexist with capitalism ingredients, there are also components of socialism.

\section{THE BASIC FRAMEWORK OF BUKHARIN'S IDEAS ABOUT THE RELATIONSHIP BETWEEN PLANNING AND MARKET}

The socialist economic construction, Bukharin considered necessary to properly handle the relationship between planning 
and the market. Whether planned or market economy and the allocation of resources are the means of regulation. However, since at the time of the Soviet economy, the state-owned economy and cooperatives dominant economy in the national economy, which led directly to the construction of a planned economy is the dominant economy. Bukharin advocates on the one hand, development plans should be coordinated within itself, in equilibrium, the lack of a unified plan of arrangement or errors occur, or if the plan itself is a problem, then the economic development will be a problem. Therefore, in the planning of economic development, we must realize the coordinated development between the various sectors of the national economy, avoiding one-sided development or anarchy. On the other hand, in accordance with Lenin Bukharin's idea, while the implementation of the planned economy in an open market economy through the development of the country's business requirements to build a socialist economy, allowing the existence of a market economy, handling the relationship between planning and market.

\section{A. Based on National Economic Balance Theory}

Based on the Soviet Union's national conditions, Bukharin sent forth his thoughts on the balance. Bukharin emphasized social balance is a prerequisite for building a socialist economy, we must correctly handle the relationship between the six main state-run economy and private economy, industry and agriculture, heavy industry and light industry, accumulation and consumption, planned economy and market regulation, political and dialectics economic relations, so as to maintain a comprehensive, balanced and harmonious development of the national economy. On balance in the national economy, the relationship between the market and Bukharin elaborated plan, he discusses that: "Due to the economic situation of backwardness, the plan itself is also" relatively far not developed socialist society 'complete' program. We can not have 'ideal' program. "5.Under the Soviet regime, although public ownership and social production of national economic planning in a way it is possible to achieve. However, this plan needs to be achieved through the market, and constantly adjust in the economic operation, supplement and perfect6. Bukharin's theory emphasizes balanced economy in the national economy, the various economic sectors combined with each other and keep the ratio of the balance between the various departments. Pay attention to the planned economy and market economy combined and keep a balanced proportion between the various sectors of the national economy.

The relationship between market and planned economy is balanced on one of Bukharin content, under the correct understanding of the relationship between the market and plan to better understand the premise of the national economy homeostasis. Balanced development of the national economy is a dynamic balance, to achieve this balance is mainly based on respect for the law of value, the importance of the role of market regulation, to achieve the balance of the entire socio-economic. Although there are a variety of relationships during the transition period, but the relationship between planning and the market is more important content, according to Bukharin's point of view: "Relatively unplanned transition economies or relative planned - is built in the form of small economies and market linkages, that there is a lot of anarchy ingredients on the basis of" 7 . In this view, the market impact of far-reaching significance of other economic sectors. Bukharin proposed Proportion handle industry and agriculture, manufacturing and construction, between accumulation and consumption, the dynamic balance of the national economy, mainly due to planned and properly handle the relationship between the proportions of the market. Agriculture and industry in the development of the national economy are mutually reinforcing, and the market is the most effective mechanism for adjusting the relationship between the two.

The main features of the socialist planned economy is the economy, the plan is to achieve national economic sectors planned, proportionate and coordinated development. Under the premise of a socialist economy, on the one hand we must keep a balance between the proportion of the various sectors of the national economy. On the other hand, properly handle the relationship between a planned economy with a large presence of relatively unplanned market economy, the resulting coordination of the planned economy with market regulation. Based on national economic equilibrium theory, Bukharin tells us a good plan and market actively homeostasis is very important. We strive to be planned and market economy combines to jointly promote the balanced development of the national economy.

\section{B. Through the Market toward Socialism}

In terms of market theory, Bukharin's main contribution is that he made it clear that the market is not bypassed, but to use the relationship to build a socialist market such a very visionary ideas .He proposed a new model of economic planning and operation of spontaneous market should combine conscious, but also pay attention to the dialectical relationship between the market and plans to develop the productive forces, lay the necessary foundation for the construction of socialist material, and then gradually transition to the community doctrine.

Market relations Bukharin thought that the market relations are a means to develop socialism is the goal. Although the proletariat to grasp the country's economic lifeline, the formulation of national economic policy of the proletariat has a certain relative. Plans to reduce blindness and spontaneity market, so that the benefits and advantages of market regulation combined with the planned economy, the various economic sectors are mobilized to promote the development of the socialist economy.

Bukharin though market economy as the link between the state and society. The market is a combination of interests of different classes, with the market through the exchange of more equitable, rational and efficient. He clearly recognized: "Each class through economic form, by market, by the amount of goods, by adjusting the amount of these commodities, the amount of these commodities by possession, by the relations of production and market relations unfold through struggle "8. Bukharin's idea is that state-owned enterprises and cooperatives can be used on the way to fight the market through market relations, through competition, crowding out their competition by that private capital. Finally, the development of market relations will destroy itself, all products will be allocated by the state and unions are replaced9. 
Under the direction of socialism through the market ideology, Bukharin stressed the need to deal with the dialectical relationship between planning and the market. Bukharin in proposing this idea, emphasizing the long-term existence of market relations. Bukharin recognized that: "This form of market relations in a very long period will continue to be decisive in the form of economic relations"10. Market relations in the socialist economic relations in the long term to play a decisive role is an objective fact, the socialist countries should be economic development through market relations is essential. Since the existence of market relations with necessity, and plans to have a relative in nature, it must maintain and develop market relations, with a planned economy to market relations combine to play an active role in the market economy.

According to the theory, Bukharin emphasized in economic development of the Soviet Union, the active use of market relations, to play the role of market regulation, and efforts to mobilize all positive factors in terms of building a socialist economy.

\section{Based on the Theory of the Theory of Socialism}

Fourth Congress of the Communist International, Bukharin made a report on the program issues of commenter. In this report, Bukharin pointed out long into the concept of socialism. He said the process into socialism, "production and distribution in the form of socialism on the basis of access to greater and greater, and all residual basic capitalism will gradually be squeezed out, direct capitalist society was completely transformed into a socialist society "11. Bukharin considered in this process, market relations play an important role. Bukharin raised questions how to arrange the ratio between these two forms of production in the report. He believes that planning and the market must maintain a reasonable proportion. Proletariat can not do everything in the economy, Bukharin said, "We must always be careful not to do anything beyond the limits of things, do not do anything from the standpoint of the political struggle of view is appropriate, but from an economic point of view is unreasonable things 12 ".

Bukharin emphasized the plan and the market should maintain a certain proportion of political intervention in the economy can not be too much in this report. To form two kinds of production to adjust to a reasonable proportion, this is for a supplement into socialism.

\section{THE MAIN CHARACTERISTICS OF PLANNING AND MARKET RELATIONS}

\section{A. Both Combined with Each Other and Promote Each Other}

Bukharin's analysis of the actual situation in Russia, he found that the coexistence of various economic sectors, and the peasant economy in the position of advantage in the national economy. To achieve a combination of Russian industry and agriculture, to achieve a balanced economy, we need to take advantage of market relations in a timely manner. However, productivity in Russia was very backward and unbalanced development, these issues objectively impossible to implement the decision of the Russian production immediately after the victory of the socialist revolution in public ownership.
Therefore, there is a relationship between the commodity and money relations in the field of production. During the transition period, the production of all forms of ownership is still in an immature stage, between state-owned enterprises with relatively independent of material interests, and thus there is a commodity relations. The existence of market relations was an objective reality.

Transition in the economy, it has an important role in the market. Market competition can effectively prevent the State intervention in the economy brought about by the inefficiency and bureaucracy and corruption problems in the industrial monopoly. Thus, the economic transition period is not to abolish markets, but to take advantage of market relations and promoting the socialist transformation of the transitional period, to achieve the combination of planning and market and promote each other, and jointly promote the development of social economy.

\section{B. Plans to Major Status, a Secondary Market Position}

In a socialist society, the plan dominant is unquestionable. Bukharin believed that in the socialist countries, the state of the economy and economic cooperation and collective dominant position in the national economy, adhere to the ideal goal of socialism is not shaken. However, the plan does not have the complete transition period; therefore, market regulation is planned regulation adjunct, from economic development to the regulation. After the implementation of the New Economic Policy, Planning and Bukharin began to re-recognize the relationship between the market, the need to discuss the implementation of market regulation, how to do market regulation, and to plan and market together, mutual promotion and other issues. Bukharin though we should regulate the use of market regulation as an adjunct program to deal with the peasant economy of private capital, private capital with the socialist state economy, the relationship between peasant economy with the economy of the state. These relationships are mainly achieved through the market.

Although Bukharin advocated the introduction of market relations in the economic transition period, but market relations is still a "socialist economic alienation factor" 13 in the concept of Bukharin. After the end of the transition period, we entered the communist society, market relations to launch the stage of history. Bukharin introduction of market relations is a policy based on the Soviet Union's national conditions taken, which is essentially upheld plan. Therefore, on plans to market relations, Bukharin insisted that the plan dominated the market for the assistance, both to maintain a certain reasonable proportion.

We should clearly understand that Bukharin on a combination of planning and market perspectives and our socialist market economy today, there is a difference. The two can not be equated. In Bukharin's thought, socialist economy is not a commodity economy, but to build socialism and the national economy to achieve a balance must be long-term use of market relations. After a long time of market competition to achieve the planned economy .However, plans and ideas Bukharin market relations is still instructive for our understanding of the socialist market economy. 


\section{REFERENCES}

[1] Ren Xiaowei: < History and theory of the origin of the socialist planned economy>, Beijing: People's Publishing House, 23.

[2] Huhong, Ji Yuxiang:<former Soviet Union seven years" reform "documentary">, Beijing: Red Flag Publishing House, 1992,58.

[3] < Selected Works of Bukharin(second volume )>,Beijing: People's Publishing House, 1981,99.

[4] Cheng Enfu: <Marxism History of Economic Thought (Soviet Russia volumes) $>$,Shanghai: Oriental Publishing Center, 51

[5] < Selected Works of Bukharin(second volume) $>$,Beijing: People's Publishing House, 1981,276.

[6] Zeng Tianxiong: " On the Balance Theory of ByxapNH's Thought on Socialist Economic Construction " Journal of ChenZhou teachers colleage, 2000 .

[7] < Selected Works of Bukharin $>$ second volume ,Beijing: People's Publishing House, 1981,276.

[8] < Selected Works of Bukharin(First volume)> ,Beijing: People's Publishing House, 1981,364.

[9] Jiang Fuxin: " Bukharin and the New Economic Policy - On the development of the socialist commodity economy thinking ", Journal of Nanjing Normal University (Social Science Edition), 1992.

[10] Zheng Yifan: $<$ Bukharin on the draft $>$ Beijing: Central Compilation and Translation Press, 1997.394-395.

[11] < Selected Works of Bukharin(First volume)>,Beijing: People's Publishing House, 1981,63.

[12] < Selected Works of Bukharin(First volume )>, Beijing: People's Publishing House, 1981,65.

[13] Hu Jian: <Economic Thought Bukharin transition period>, Xi'an: Shaanxi People's Education Press, 193. 